\title{
Universities confront changing markets
}

Tertiary education is a competitive business with growing export potential. A recent report highlights the importance of postgraduate training, but governments are undermining universities' abilities to compete in an expanding market.

IMAGINE a young and ambitious businesswoman, with a degree in computing and with several years' employment in a growing company. She is convinced that both she and her employer would benefit if she studied the application of computers applied to commerce and industry. She has to balance family and work commitments, so cannot simply move to an appropriate college. But she plugs into the World Wide Web, clicks into a search engine, specifies "online education", and discovers that the Open University can provide her with an online Masters course. Her employer will pay the full costs of the course, she is prepared to put in the hours needed to gain a significant qualification without sacrificing other commitments, the university will gain another customer, and no government has to subsidize the deal.

That scenario (which is possible today) represents a glimpse of a burgeoning market for higher education institutions, and an increasingly attractive one: taught courses for postgraduates, as distinct from research. The students are, increasingly, part-time and mature, and have access to private finance, whether their own or their employer's. Postgraduate science is dominated by research-based studies, but advanced taught courses, delivered locally or at a distance, are becoming increasingly saleable commodities. In a report published in the United Kingdom last week, Professor Martin Harris and colleagues provide the first overview of postgraduate education across all disciplines in British universities (see page 266). The report highlights the differences in support mechanisms and market potential between postgraduate taught and research degrees, showing that the growth of the former is now the fastest expanding component of university activity.

But this growth has been stimulated mainly by the need for universities to find money. Government resources for undergraduate education have diminished while undergraduate numbers have, until recently, grown. And government funding for research is tightly constrained, with support for infrastructure in steep decline. In developing new teaching courses while under such strain, there is a real risk that universities will give less value than is acceptable. The Harris report therefore provides a useful service by focusing on constraints and opportunities in postgraduate teaching and research. It is right to emphasize the primary role of individual institutions rather than national agencies in establishing the diversity of taught courses that can be supplied, while insisting that customers should not be confronted (as they are now) with a confusing plethora of course titles, with inadequate description of just what will be delivered. But it is realistic also in emphasizing the need for institutions to recover progressively more of the full cost of taught courses from the students themselves.

Guaranteeing quality will be crucial to this growing export industry, in the United Kingdom, in Australia (see page 265), and elsewhere. In the traditional university model, research has the added value of underpinning teaching quality. The Harris report accepts the nontraditional (in the United Kingdom) but increasingly realistic view that postgraduate teaching and research are distinct and separable activities. Controversially, it states that government support for postgraduate research should be selectively based on an institution's achievements in the periodic research assessment exercise carried out by higher education funding councils. It is right, however, to insist that funds for undergrad- uate education should be protected, and that postgraduate taught courses should also be targeted for support by the funding councils but supplied within a more market-led and commercial approach.

But there is a question begged in all of this: is the system as a whole in good health? For an answer one has to refer instead to the much more critical document, Research Capability of the University System, produced last month by the UK National Academies Policy Advisory Group (see Nature 380, 571; 1996). Its identification of "tensions and irreconcilable contradictions" provides salutary warnings. Shortcomings in the research assessment exercise, overemphasis by research councils on technology foresight, obstacles to interdisciplinary and innovative research are just some of the problems highlighted. Unless they are addressed by the government, the potential benefits of the Harris report's recommendations on research training will be undermined. And unless undergraduate training receives the government support it requires, the market-led teaching of postgraduates will also be damaged. In both respects, the United Kingdom's ability to realize what it can offer postgraduate students is under threat.

\section{Treaty on the brink?}

India should not threaten the success of the Comprehensive Test-Ban Treaty in its quest for disarmament.

INDIA deserves some credit for consistency and a lack of hypocrisy in nuclear affairs. It refused to sign the Non-Proliferation Treaty (NPT) and exploded a nuclear device in 1974. Provocatively, the three weapons states negotiating the treaty - the United States, Russia and the United Kingdom - were trying to limit nuclear proliferation while continuing to develop their own arsenals. India now suspects that while the Comprehensive Test-Ban Treaty (CTBT) under negotiation at Geneva (see page 267) will prevent weapons proliferation, it will not commit the nuclear powers to disarming. But in seeking such commitments in advance, India is asking too much of the real world.

A test-ban treaty was the price that the nuclear powers paid for last year's agreement among nonnuclear states on an indefinite extension of the NPT. Had the nuclear enthusiasts in the Pentagon got their way in demanding that the ban exempt small nuclear explosions, India would have been right to cry foul. But President Bill Clinton adhered instead to independent scientific advice which said such tests were not needed to guarantee the safety of the stockpile. All five nuclear powers now agree, with the result that the treaty under discussion at Geneva is more unequivocally comprehensive than anyone could have hoped for.

Agreement on a test ban is not an event in itself, but the beginning of a long process. By freezing the gap between the weapon haves and have-nots, a test ban will create better conditions for further talks on disarmament. But without a CTBT the NPT will be weaker, and the risk that dictators will obtain - and use nuclear weapons will be greater. It would be a shame if India, which called for a test ban as long ago as 1955 , should be the one to scuttle the ship as it pulls into port. 